\title{
THE SURVIVAL OF POWERS OF JOINT EXECUTORS TO SELL LAND
}

\section{Alvin E. Evans $\dagger$}

One distinction between real and personal property at common law was that personalty descended to the personal representative, while land descended to the heir. ${ }^{1}$ The former, accordingly, was used to pay debts and legacies. There was little restriction upon the power of one of several executors to dispose of the personalty. Land, however, was not liable for the payment of debts, save where the debtor purported to bind the heir by a bond, and even then the debt could be avoided by a devise to some other person. Successive English statutes made land in all cases subject to sale to pay debts of all kinds, including those tort claims that survived death: Finally, in England and in a few American states, this one distinction between realty and personalty was largely wiped out by statutes, causing both types of property to descend to the personal representative, at least for the purpose of paying debts. But in most of the American states land still descends to the heir, as if the practice accorded with some law of nature rather than with feudal principles. In all these states, however, it is made subject to the payment of debts, the particular procedure for this purpose varying among the states. Nevertheless, the relatively free hand which executors have for the disposal of personal property has in no case been extended to sales of land.

After the enactment of the original Statute of Wills, ${ }^{2}$ it became possible to devise land to executors or trustees to be sold and to give instructions for the application of the proceeds. Much the same result also obtained before this statute by the devise of the use. Even without devising the land, a power of sale could be created in a will, to sell with directions as to the disposal of the proceeds. If only one executor were named and he refused the office, died, refused to act, came under a disability, or was removed for cause, the power failed because it constituted a "special trust", which was outside the ordinary duties of the executor and so was regarded as personal. Partly to avoid such a contingency, and partly to have the advantage of the combined judgment and discretion of more than one person, the practice arose of naming several executors or trustees. The courts, however, construed the power as one attaching to the persons of all those named, so that on the failure for any cause of any one named to perform, the power also

$\dagger$ A. B., I898, Cotner University; A. M., I898, University of Nebraska; Ph.D., I908, J. D., I9I8, University of Michigan; author of various articles in legal periodicals on the law of real property; Dean and Professor of Law, University of Kentucky College of Law.

I. 2 Pollock and Maitland, History of English LaW (2d ed. I898) 334, 360 .

2. 32 HeN. VIII, c. I (I540). 
failed. $^{3}$ To remedy this situation, but in one respect only, the survival statute of Henry VIII ${ }^{4}$ was enacted. Its terms applied to those cases where a power was granted to joint donees, but only when some of them refused to assume the duties. 5 Thus it left all other cases above mentioned unprovided for. It clearly was not intended to apply to cases where personal' performance by all was desired, but it made no express distinction between mandatory and discretionary powers, or naked powers and those coupled! with an interest or with a trust, or whether they were granted individually, nominatim, or were official, attaching to the office rather than to the individuals. These distinctions grew up sharply when the courts were called upon to interpret the statute.

There are two preliminary matters to be disposed of before survival is considered. One has to do with the result where not all the existing donees join in the exercise of the power. The other suggests a comparison of the power to convey with the power to consent or withhold consent to the conveyance.

\section{Joint Action by Donees}

Suppose a testator appoints $A, B$ and $C$ his executors and directs them to sell his property and apply the proceeds in a certain way. Whether $A$ and $B$ can exercise the power if $C$ should die is a problem of the survival of powers. But if $C$, while still an existing and qualified executor, does not join in the exercise of the power either from wilfulness or from inadvertence, a different problem is raised, namely, shall the estate pass through a conveyance made by $A$ and $B$, who constitute a majority? Does the unity concept, according to which the acts of some are regarded as the acts of all, apply to the exercise of the power to sell land? If $C$ while still an executor need not join in order to pass the title, a fortiori the conveyance should be valid in the event that $C$ 's co-operation should become impossible for any reason such as his death.

In the absence of a provision to the contrary, such as a grant to "my executors or a majority of them," it is usually held to be necessary for all the executors qualified at the time of sale to join in the execution of the conveyance. $^{6}$ This requirement is justifiable, first, because a high degree of R. 826

3. See Kates, Estates, Future Interests (2d ed. I920) 713; Note (Ig25) 36 A. L.

4. 2 I HEN. VIII, C. 4 (I529).

5. See Co. LitT. *II3a; Kales, op. cit. supra note 3, at 7I4; 2 WoERnER, AMarrican LAW OF ADMIINISTRATION (3d ed. 1923) \$34I; Note (1925) 36 A. L. R. 826.

6. See Dodge v. Tullock, IIo Mich. 480, 68 N. W. 239 (I896); Crane v. Decker, 22 Hun 452 (N. Y. r880) ; Oil City Nat'l Bank v. McCalmont, 303 Pa. 306, I54 Atl. 497 (193I). See Page v. Gillett, 26 Col. App. 204, I4I Pac. 866 (19I4) (recital in deed by two or three trustees that the third one is dead is not evidence of that fact); Bascom v. Weed, 53 Misc. 496, 105 N. Y. Supp. 459 (Sup. Ct. I907) (where one co-executor becomes a lunatic, the others cannot sell land without first applying for removal); Wright v. Dunn, 73 Tex. 293, II S. W. 330 (1889) (power in three executors to convey must be executed by ali). 
discretion and judgment is contemplated; secondly, because the power to sell land is not a common-law function of executors but constitutes a "special trust"; and finally, because the testator may be regarded as having stipulated for a joint exercise. The rule that all must join applies as well to those whose consent is necessary as a prerequisite to the exercise of the power of sale. $^{7}$

Though a conveyance may be invalid because it was executed by fewer than all, still it may be ratified subsequently by those who originally failed to join in it, at least where no intervening rights have arisen. ${ }^{8}$ It is sometimes said that the title passes in equity in such a case if full payment has been made and the transaction was in good faith, and in this way a basis may be laid for quieting title. ${ }^{9}$

There is some authority for the view that the purchaser gets only an equitable lien for the return of his purchase money and for whatever value he has added to the premises by way of improvements. ${ }^{10}$ In several states by statute one co-executor may grant a power of attorney in writing to an associate to sign the name of the former to the conveyance. The assumption is that the discretionary function has been performed and the attachment of the name to the conveyance is a mere ministerial requirement. ${ }^{11}$

Assume that the power is one that would otherwise survive but that the remaining donees are granted authority to fill vacancies that may develop in their ranks, must the accruing vacancies be filled before the power can be exercised? It is evident that a clear expression of intent by the testator

7. Farwell, Powers (3d ed. rgi6) I49-I50; Sugden, Powers (8th ed. I86I) 252, I7 7.

8. Smith v. Shackleford, 9 Dana 452 (Ky. I840); Baines v. Drake, 50 N. C. 153 (I857); Silverthorn v. McKinster, I2 Pa. 67 (r849); Giddings v. Butler, 47 Tex. 535 (1877); Mills v. Mills, 28 Gratt. 442 (Va. I877); Dunn's Ex'rs v. Renick, 40 W. Va. 349, 22 S. E. 66 (1895); cf. Loew v. Bedford, I25 Misc. 866, 212 N. Y. Supp. 302 (Sup. Ct. I925).

9. Brown v. Doherty, 185 N. Y. 383, 78 N. E. I47 (1906); Silverthorn v. McKinster, 12 Pa. 67 (I849) ; Giddings v. Butler, 47 Tex. 535 (I877). But see McRae v. Farrow, 4 Hen. \& Munf. 444 (Va. 1809).

10. Clark v. Hornthal, 47 Miss. 434 (1872).

II. See infra note I30 for the citations to statutes. Cf. Armor v. Frey, 253 Mo. 447, I6I S. W. 829 (I9I3). In California, the failure of one co-executor to sign the conveyance has been held to constitute only a formal defect and the legal title passes if in fact all consent to the sale. See Panaud v. Jones, I Cal. 488 (I85r). In Denne v. Judge, II East 288 (K. B. I809) there were five executor-trustees. Three signed the conveyance, but all consented to the sale. Held, a three-fifths interest passed and the purchaser became a tenant in common with the two joint tenants who failed to sign the conveyance. It was intimated that if they had sold as executors the entire interest might have passed. If, however, they signed as trustees it would seem that no interest would pass and it is difficult to see how they could have signed as individuals.

A power of sale does not warrant an exchange, Columbus Ins. \& Banking Co. v. Humphries, 64 Miss. 258, I So. 232 (I887) ; Taylor v. Galloway, I Ohio 232 (I822) ; nor the granting of an option of purchase, Trogden v. Williams, r44 N. C. I92, 56 S. E. 865 (1907); nor permit the donees to mortgage the land, Kinney v. Matthews, $69 \mathrm{Mo} .520$ (I879). There is no sufficient reason why a survival statute should not be retroactive, Bredenburg v. Bardin, 36 S. C. I97, I5 S. E. 372 (1892) (so held because it was remedial). Contra: Geddy \& Knox v. Butler, 3 Munf. 345 (Va. I8I2).

On the question of the necessity of the presence of all the donees at the public sale see Dunn's Ex'rs v. Renick, 40 W. Va. 349, 363, 22 S. E. 66, 7I (1895); Note (1913) 50 L. R. A. (N. s.) 622 . 
should be complied with. ${ }^{12}$ If the language does not manifest such an intent, the survivors may make the conveyance without first filling vacancies. ${ }^{13}$

Whether the survivor may sell and whether all qualified must join in the sale should be determined by the law of the state where the land lies rather than by the law of the domicil. ${ }^{14}$ A case in Illinois throws some possible doubt upon the rule in that state. ${ }^{15}$ One of the executors, a corporation, had qualified at the domicil but had not qualified in Illinois. It was held that a conveyance by those who alone qualified did not pass title. ${ }^{16}$

\section{Where $X$ 's Consent to the Sale Is Reguired and $X$ Dies Before a SAle Is Made}

Suppose the testator authorizes the sale of his land by his executors but requires that they must first obtain the consent of $X$, or of $X$ and $Y$, as a condition to conveyance by them. It is clear that the power of $X$ or of $X$ and $Y$ to grant or withhold consent is something different from the power to convey, though it bears a certain analogy to such a power. It has already been seen that it is quite as necessary for all who have this power of granting or withholding consent to join as it is for all the donees of the power of sale to join.

However, if there are two whose consent is required and one dies, there is no question of the survival of a power to consent. The doctrine of survival of powers is inapplicable, because, unlike the power to sell, which attaches to the office of executors, the power to consent or to withhold consent is a personal power. If the requirement that $X$ shall join in consenting is dispensed with after $X$ 's death, or if the consent of $X$ alone is required and $X$ dies before the conveyance is made, and a conveyance may still be made by those who had this conditional power to convey, it is because the court by construction determines that the testator did not intend to make a conveyance impossible under the circumstances that have arisen.

I2. O'Brien v. Battle, $98 \mathrm{Ga} .766,25$ S. E. 780 ( 1896 ) (vacancy to be filled first).

13. Golder v. Bressler, 105 I11. 419 (1883) ; Parker v. Sears, II7 Mass. 513 (I875); Ogden v. Smith, 2 Paige I95 (N. Y. Ch. I830); Belmont v. O'Brien, I2 N. Y. 394 (1855); Philadelphia Trust Co. v. Lippincott, ro6 Pa. 295 (I884); Note (I908) I30 Am. St. Rep. 508, 5 II-5I3; cf. Dingman v. Boyle, 285 I11. I44, I20 N. E. 487 (I9I8) ; Reid v. Reid, 30 Beav. 388 (Rolls Ct. I862).

I4. Correll v. Lauterbach, I2 App. Div. 53I, 42 N. Y. Supp. I43 (Ist Dep't, I896), aff'd, I59 N. Y. 553, 54 N. E. I089 (I899); 2 BEALE, CONFliCT OF LAWS (I935) \$ 233.3.

I5. Pennsylvania Co. v. Bauerle, I43 Ill. 459, 33 N. E. I66 (1892). See Acorn Wood Realty Co. v. Old Colony Trust Co., II3 Fla. 320, I5I So. 533 (I933) ; Eastman Co. v. Anyon, II6 Fla. 137, I56 So. 302 (1934). The latter case adopts the erroneous view that the unity concept applies and the act of one is the act of all.

16. This result, however, may also be accounted for by the rule which seems to prevail in Illinois and Pennsylvania, which, following the ecclesiastical practice, requires a renunciation in writing which must be recorded. It seems that a later qualification and ratification might have cured the defect. Qutaere whether a later renunciation might also have sufficed. See Neel v. Beach, $92 \mathrm{~Pa}$. 22I (I874). On the requisites for valid renunciation, see Note (I925) 36 A. L. R. 826, 846 . 
Sugden says ${ }^{17}$ that where the consent of any person is required to the exercise of the power, like every other condition, it must be strictly complied with. So it is declared that whatever arbitrary terms the grantor of the power may impose or however absurd or unreasonable they may seem to be they must be fulfilled. ${ }^{18}$ There should be no debate about this matter where it is clear that the testator meant such provision as a true condition precedent. Farwell ${ }^{19}$ agrees with Sugden, cataloguing those cases upon which Sugden had relied. But he cites some subsequent cases wherein such strict compliance was not required. Thus, where a testator gave his son a power to make a jointure to his wife if he should marry with the assent of $A$, it was held that the testator intended to impose this obligation only so long as $A$. was capable of assenting. ${ }^{20}$ Likewise, in an earlier case, authority to convey lands to testator's daughter on condition that if she married she should do so only with $A$ 's consent was held to be sufficiently complied with where the daughter married in testator's lifetime with his own consent. ${ }^{21}$ Thus in England there was a breaking away from the earlier strictness.

This exact situation has not often arisen in this country, but there are at least five decisions squarely in point. One court adopts Sugden's view without much discussion, though it would appear that the requirement that the widow should consent was not intended to continue after her death. ${ }^{22}$ Another, without assigning any reason, holds that such a condition is excused. ${ }^{23}$ A third decision excuses the performance of the condition partly because of what it regards as the clear intent of the testator and perhaps partly because of the survival statute, ${ }^{24}$ though one may infer that this result would have been reached had there been no such statute.

The English courts came to the point of ignoring the rule to such an extent that the testator's intention was palpably violated, and it was Sugden's opinion that the insertion of the words "if living" would have made no difference. $^{25}$ Concededly, a clear intent will not be violated; it then becomes

I7. Sugden, loc. cit. supra note 7.

I8. Rutland v. Wythe, 10 Cl. \& Fin. 4I9 (K. B. I842). 731.

19. Farwell, op. cit. supra note 7, at I6I-165. See also Chance, Powers (I83I) กा 727-

20. Green v. Green, 2 J. \& La T. 529 (Irish Ch. 1845).

21. Clarke v. Berkeley, 2 Vern. 720 (Ch. I7I6).

22. Peirsol v. Roop, 56 N. J. Eq. 739, 40 Atl. I24 (I898). In Barber v. Cary, II N. Y. 397 (1854) the power of sale was conditioned upon the prior consent in writing of $A$ and $B$. $A$ having died, the executor conveyed the premises to $B$. It was held that the transfer to $B$ was not a transfer with the written consent of $B$, and though $B$ is estopped to object, others may not be. Further, the court said that there is a difference between the power to convey and the authority to consent. The power can be exercised only by those who can alien, and to them the doctrine of survival may apply, but it does not apply to those who have authority to consent only. See also Gulick v. Griswold, I60 N. Y. 399, 54 N. E. 780 (I899).

23. Hackett v. Milnor, I56 Pa. I, 26 Atl. 738 (1893).

24. Wisker v. Rische, 167 Mo. 523, 67 S. W. 218 (I902). Cf. Oil City Nat. Bank v. Mc-

Calmont, $303 \mathrm{~Pa} .306$, I54 Atl. 497 (I93I).

25. SUGDEN, op. cit. supra note 7 , at 253. 
important to look for such indications as may point out the testator's desire, and it is conceived that such factors as these may be significant: was the requirement intended for the benefit of the person consenting or for other persons; is such person a beneficiary, or is he entirely without personal interest; do others still live whose consent is required and, if so, are they the only ones interested; would the testator have desired the same result if the person whose consent was required had not died but rather had become insane?

It is now possible to examine more conveniently the problem of the survivability of testamentary powers to sell land and to classify them according to their characteristics.

\section{Powers of Sale Personal or Offictal}

Does it make any difference whether a co-executor fails to join in a conveyance because of wilfulness or inadvertence, the consequence of which has just been discussed, or fails to join because his own death or some other cause has made his co-operation impossible? The doctrine of survivorship is based upon the assumption that there is a difference. It is now necessary to discover what powers may and what powers may not survive and the reasons in each case. If the testator intended to give the power to coexecutors as persons filling a certain office, it was assumed that the power attached to the office rather than to them as individuals. But if the power were granted independently of the office, it was regarded as personal andi was assumed that the testator did not intend it to be exercised save by all. It did not therefore survive the death of any one of the co-executors.

The inclination toward a strict construction of a grant of powers led to making meticulous distinctions. Thus a grant to "my executors" was official; a grant to "my executors, $A$ and $B$ " was doubtfully official; whereas a grant to " $A$ and $B$, my executors" was personal, "my executors" being regarded as descriptio personarum. The question that the court considered was not what the testator in fact meant but rather what meaning could be placed upon the words abstractly considered so as to avoid expansion beyond the narrowest possible bounds. ${ }^{26}$ Later decisions tended to show a more liberal spirit, and thus the conclusion was reached that such descriptions as "my executors herein named" indicated an official rather than a nominatim appointment. ${ }^{27}$

26. See the five conclusions in Sugden, op. cit. supra note 7 , at I28; In re Smith, [1904] I Ch. I39. For the unsatisfactory statements of commentators, see Kales, Survival of Pouvers as Unaffected by Statutes (I9I2) 6 ILL. L. Rev. 447, 455.

27. Crawford v. Forshaw, [I89I] 2 Ch. 261 ; see Robinson v. Allison, 74 Ala. 254 (I883); Trustees of Putnam Free School v. Fisher, 30 Me. 523 (I849); Chandler v. Rider, I02 Mass. 268 (1869); Bartlett v. Sutherland, 24 Miss. 395 (1852); Gaines v. Fender, 82 Mo. 497 (I884); Fitzgerald v. Standish, I02 Tenn. 383, 52 S. W. 294 (I899); Geddy \& Knox v. Butler, 3 Munf. 345 (Va. I8r2). 
"Personal" is often confused with "discretionary", on the assumption that if the exercise of the power is discretionary it would necessarily call for the personal judgment of the named donees. ${ }^{28}$ But while it is true that discretion may be one element, it is not to be conclusively assumed that the exercise was intended to be personal. As often pointed out by the courts, the naming of any one to the office indicates a special confidence in that person but it does not establish as a fact that the testator desired that only" those named, and all of them, should exercise the power, and that otherwise he would prefer to have the power fail. Thus a discretionary power coupled with title, called by $\mathrm{Mr}$. Kales a spurious power, ${ }^{29}$ is not limited to the donees and is accordingly not personal. ${ }^{30}$.

\section{Where Donees of the Power Are Invested With the Estate}

The survival statute of Henry VIII did not expressly apply to the socalled powers of sale where the estate was also devised to the donees, nor did it expressly distinguish between mandatory and discretionary powers. In Lane v. Debenham, ${ }^{31}$ the leading case, the estate was devised to two of the executors, and they were authorized to raise a sum of money for a beneficiary "by sale of the land or otherwise". The power was clearly discretionary and would not have survived if it had not been supported by the title. It seems, then, that a statutory provision for survival is not required in such a case because title descends to the survivor or survivors, and the power is not divorced from the title. ${ }^{32}$ Earlier English cases had reached the same result both where the power was mandatory ${ }^{33}$ and where it was discretionary. ${ }^{34}$ Thus the power may be exercised though it is granted solely in aid of distribution $;^{35}$ or is discretionary and is to be exercised for the benefit of third persons $;^{36}$ or is wholly discretionary with respect to the application of the proceeds; ${ }^{37}$ or is discretionary and no purpose is stated, other than convenience in distribution. ${ }^{38}$ In New York such a title is reduced to the level of a power. ${ }^{39}$

28. Robinson v. Allison, 74 Ala. 254 (I883) ; Tainter v. Clark, 54 Mass. 220 (1847); Lanning v. Sisters of St. Francis, 35 N. J. Eq. 392 (1882); Deaderick v. Cantrell, I8 Tenn. 263 (I837) ; Armstrong v. Park, 28 Tenn. I95 (I848); Brown v. Armistead, 6 Rand. 594 (Va. I828) (distinguishes the terms); and especially Dillard v. Dillard, 97 Va. 434, 34 S. E. 60 (1899).

29. Kales, supra note 26 , at 447 .

30. Murdock v. Leath, 57 Tenn. I66 (1872).

3. II Hare I88 (V. C. I853).

32. See Trustees of Putnam Free School v. Fisher, 30 Me. 523 (I849); Farwell, op. cit. supra nòte 7 , at 267 . (I848).

33. Bonifaut v. Greenfield, r Cro. Eliz. 80 (Q. B. 1587); Watson v. Pearson, 2 Ex. 58r

34. Faulkner v. Lowe, 2 Ex. 595 (1848); In re Smith, [1904] I Ch. I39. But see Walter v. Maunde, 19 Ves. 424 (Ch. I8I5).

35. Dick v. Harby, 48 S. C. 516, 26 S. E. 900 ( 1897 ).

36. Evans v. Blackiston, 66 Mo. 437 (I877); In re Smith, [r904] x Ch. 139.

37. Bradford v. Monks, I32 Mass. 405 (I882); Donaldson v. Allen, I82 Mo. 626, 8I S.

W. II5I (Ig04); Watson v. Pearson, 2 Ex. 58I (I848); In re Bacon, [rg07] I Ch. 475.

38. Wallace v. Foxwell, 250 I1l. 6r6, 95 N. E. 985 (IgII), 50 L. R. A. (N. S.) 632 (Igr4).

39. N. Y. Cons. LAws (Cahill, I930) c. 5I, \$97. 
While speaking of those cases where a power is given to donees who are also vested with the absolute estate, $\mathrm{Mr}$. Kales said that if the donees are to distribute to persons other than the ones prescribed by the testator, the nature of the power raises the inference that it was to be exercised only by the particular persons named. ${ }^{40}$ This seems to be a plea for a construction modo et forma. His meaning, however, is not clear because it is only when the testator has not devised the estate to his trustees, and it either descends to the heirs or is willed to named devisees, that this result arises. Even so, there is no sufficient reason for a strict cunstruction. Mr. Kales' view would seem to be applicable only where the uncontrollable discretion applies to matters collateral to the sale, as, for example, a power to determine whether $A$ shall have the property or $B$ shall take it ${ }^{41}$ or a power to apportion among a class $;^{42}$ or to select the charities to be benefited $;^{43}$ or to revoke the legacies of any beneficiaries who should express dissatisfaction with the will and appoint the shares to others $;^{44}$ or to dispose of the proceeds without restriction $;^{45}$ or to sell and distribute the proceeds among the testator's relatives, the persons to be benefited and amounts to be given being determinable at the donee's unhampered discretion. ${ }^{40}$ In these cases, though the estate is not in the donees, it is still questionable whether a strict construction is desirable, and it is not a necessary conclusion that execution by the survivors was not intended. In truth, there are similar situations where a discretionary power has been held to survive. ${ }^{47}$

It did not require a survival statute in order that a surviving donee vested with the estate might sell. ${ }^{48}$ The result is the same where, instead of the fee being granted to executors, a limited beneficial interest is given to some or all of them with a mandatory power of sale. ${ }^{49}$ The technical distinction made by Mr. Kales between powers accompanying the estate in the donee, $i$. e., spurious powers, and powers in the donee without the estate,

40. KALES, op. cit. supra note 3 , at 721 .

4I. Dillard v. Dillard, 97 Va. 434,34 S. E. 60 (I899).

42. Attorney-Gen'l v. Gleg, I Atk. 356 (Ch. 1738) ; Cole v. Wade, I6 Ves. 27 (Ch. I807) ; see Reid v. Reid, 30 Beav. 388 (Rolls Ct. I862).

43. Crawford v. Forshaw, [189I] 2 Ch. $26 \mathrm{I}$.

44. Mallet v. Smith, 6 Rich. Eq. I2 (S. C. I853).

45. Naundorf v. Schumann, 4I N. J. Eq. I4, 2 Atl. 609 (I886).

46. Cole v. Wade, I6 Ves. 27 (Ch. I807).

47. Keplinger v. Maccubbin, $58 \mathrm{Md}$. 203 (I882) (power to determine whether a fair division of the land could be made and, if not, to sell, survives by statute); Jencks v. Safe Deposit Co., I20 Md. 626, 87 Atl. I03I (I9I3) (estate in the donees with power to select the tracts of land to be given each beneficiary); Vernor v. Coville, 54 Mich. 28I, 20 N. W. 75 (I884) (share of one child not to be paid till he reached twenty-five years of age, with discretion to pay sooner-estate not in the executors); Smith v. Winn, 27 S. C. 59I, 4 S. E. 240 (1887) (power to appraise and partition in the executors, title in the heirs).

48. Iane v. Debenham, II Hare I88 (Ch. I853) ; Co. LITr. * I I2b. See Wallace v. Foxwell, 250 Ill. 6I6, 95 N. E. 985 (I9II), 50 L. R. A. (N. S.) 632 (I9I4); Herrick v. Carpenter, 92 Mich. 440,52 N. W. 747 ( 1892 ).

49. Leavens v. Butler, 8 Port. 380 (Ala. I839) ; Franklin v. Osgood, I4 Johns. 527 (N. Y. I8r7). But see Ferre v. American Board, 53 Vt. I62 (I880). 
i. e., real powers, ${ }^{50}$ has significance only in this respect, that the so-called, spurious powers generally survive whether or not they are discretionary or personal.

\section{NAKed Powers}

The power is commonly said to be "coupled with an interest" if the estate as well as the power is in the donee. Suppose, however, that the testator makes no devise of Blackacre but authorizes his executors, $A$ and $B$, to sell it and distribute the proceeds to $C$. Or, suppose he devises Blackacre to $X$ but authorizes his executors to sell it and distribute the proceeds to $X$ and $Y$ or to $Y$ only. If the estate descends to the heir or is devised to another subject to the power, the power is said to be naked and did not survive at common law. After the enactment of the English survival statute and after the extensions of it in American states, to describe a given power as "naked" or as a "mere" power is to ascribe to it a quality which is largely immaterial. It amounts to saying that it belongs to that class which does not always survive. To say, however, as is sometimes done, that the survival statutes eliminate the distinction between powers coupled with an interest and naked powers is inaccurate. ${ }^{51}$ The title may descend to the heir, ${ }^{52}$ or may pass to a devisee named in the will other than the donees. ${ }^{53}$ It may be another matter whether or not a trust is created which must be exercised by the survivor, or possibly by the administrator c. t. a. or by a trustee. Sometimes the term "mere" power is used. It is not always clear whether "mere" means "naked" 54 or whether it means no trust for the benefit of third: persons. ${ }^{55}$ In any event, according to the authorities, it survived so long as a plural number of donees remained.58

The insufficiency of the term "coupled with an interest", being limited in application to those cases where the estate was devised to the donees, led to the search for a new term to characterize the cases where the donees did not have an estate but were expected to exercise the power in the interest of named beneficiaries. This power, created in the interest of certain beneficiaries, was said to be "coupled with a trust",57 and the interest of these persons was said to "feed the power." 58 In New York a rule has developed

50. KALES, op. cit. supra note $3, \S 624$.

51. Tarver v. Haines, 55 Ala. 503 (1876) ; Fitzgerald v. Standish, roz Tenn. 383, 52 S. W. 294 (1899).

52. Wardwell v. McDowell, 3I Ill. 364 (1863) ; Tucker v. Baldwin, 73 N. J. Eq. 224, 66 Atl. 928 (Ig07).

53. Probasco v. Creveling, 25 N. J. L. 449 (I856) ; Osgood v. Franklin, 2 Johns. Ch. I (N. Y. I8I6).

54. Wardwell v. McDowell, 3I Ill. 364 (I863) ; Clinefelter v. Ayers, I6 III. 329 (I855) (statute applies to a "mere" power where there is a trust).

55. See Peter v. Beverly, ro Peters 532, 564 (U. S. I836) ; Clinefelter v. Ayers, I6 Ill. 329 (1855) ; Muldrow v. Fox, 2 Dana 74 (Ky. r834); Berrien v. Berrien, 4 N. J. Eq. 37 (Ch. 1837) ; Fitzgerald v. Standish, 102 Tenn. 383, 52 S. W. 294 (1899).

56. Cf. Muldrow v. Fox, 2 Dana 74 (Ky. I834); FARWELt, op. cit. supra note 7, 2t 515 . 57. Peter v. Beverly, Io Peters 532, 564 (U. S. I836).

58. Osgood v. Franklin, 2 Johns. Ch. I (N. Y. I8I6). 
which denies that the power is exercisable by the survivor if the latter was both executrix and beneficiary of the trust. ${ }^{59}$ It is believed, however, that apart from statute such a survivor, usually the widow, should not be denied the exercise of the power. ${ }^{60}$

A power of sale to pay debts undoubtedly is a power coupled with a trust which survives. ${ }^{61} \mathrm{Mr}$. Woerner says that where an executor sells land under a power to pay debts the purchaser is not bound to inquire whether there are any debts in order to be protected. ${ }^{62}$ This is also the English rule, ${ }^{63}$ and is wholly a desirable one, and inasmuch as the purchaser has no sufficient means of discovering the condition of the estate he should be able to rely upon the terms of the will. Several states have held, however, that no valid sale can be made to carry out the special purpose for creating the power, such as the payment of debts, unless such object actually exists. ${ }^{64}$

\section{Powers Mandatory or Discretionary}

A naked power may be mandatory or discretionary. The strongest case would arise where a mandatory power is exercisable for the benefit of persons who would not otherwise take by devise or descent. The weakest form is a discretionary power where no reason for its exercise is given. ${ }^{65} \mathrm{Be}$ tween the two are mandatory powers where no purpose is stated and discretionary powers, the exercise of which disappoints the heir or devisee. ${ }^{66}$. The leading case is Howell $v$. Barnes ${ }^{67}$ where a mandatory power, the exercise of which would disappoint the heir, was held to survive. ${ }^{68}$ So, too, a mandatory power requiring the performance of active duties survives, being coupled with a trust. ${ }^{69}$

59. Correll v. Lauterbach, I2 App. Div. 53I, 42 N. Y. Supp. I43 (Ist Dep't I896), aff'd, I59 N. Y. 553, 54 N. E. 1089 (1899); Haendle v. Stewart, 84 App. Div. 274, 82 N. Y. Supp. 823 (Ist Dep't, 1903) ; Hilton v. Sowenfeld, 53 Misc. 152, I04 N. Y. Supp. 942 (Sup. Ct. 1907).

60. Weimer v. Fath, 43 N. J. L. I (I88I); a fortiori where the donees are devised the estate. See Watson v. Pearson, 2 Ex. 58r, 594 (1848); Faulkner v. Lowe, 2 Ex. 595 (1848); In re Bacon, [1907] I Ch. 475 .

6I. Peter v. Beverly, Io Peters 532, 564 (U. S. I836) ; Phillips v. Stewart, 59 Mo. 49 I (1875); Weimar v. Fath, 43 N. J. L. I (I88I); Jackson v. Ferris, I5 Johns. 346 (N. Y. I818); Fitzgerald v. Standish, 102 Tenn. 383, 52 S. W. 294 (1899).

62. 3 WOERNER, op. cit. supra note $5, \$ 1602$.

63. Forbes v. Peacock, II M. \& W.630 (Ex. 1843).

64 Floyd v. Johnson, 2 Litt. I09, II5 (Ky. I822); Rosebloom v. Mosher, 2 Denio 6r (N. Y. I846); Mayes v. Blanton, 67 Tex. 245,3 S. W. 40 (I887) ; Roberts v. Connelle, $7 \mathrm{I}$ Tex. II, 8 S. W. 626 (I888).

65. Bartlett v. Sutherland, 24 Miss. 395 (1852); Meredith's Estate, I Pars. Cas. 433 (Pa. 1850).

66. E. g., Chandler v. Rider, ro2 Mass. 268 (I869).

67. Cro. Car. 382 (K. B. I634).

68. See Forbes v. Peacock, II M. \& W. 630 (Ex. I843).

69. Taylor v. Banham, 5 How. 233 (U. S. I847); Wilson v. Snow, 228 U. S. 217, 223 (Igr3) ; Warden v. Richards, II Gray 277 (Mass. I858); Phillips v. Stewart, 59 Mo. 491 (I875); Conklin v. Egerton, 2I Wend. 430 (N. Y. I839); Farrar v. McCue, 89 N. Y. I39 (1882); Mott v. Ackerman, 92 N. Y. 539 (1883); White v. Taylor, I Yeates 422 (Pa. I795); Dick v. Harby, 48 S. C. 5I6, 26 S. E. 900 (I896). 
It is commonly declared that mandatory powers survive unless they are personal ${ }^{70}$ or are made nominatim, whereas discretionary powers do not survive at common law or under the statutes. ${ }^{71}$

In most of the cases where a discretionary power has been held not to survive the exercise was not in the interest of creditors or legatees, and frequently the power was not coupled with active duties to be performed over a period of time. It was to be exercised for convenience of administration and to avoid the necessity of partition proceedings. Sometimes the court regards a power as mandatory, though discretionary in form, where the execution of it is beneficial to third persons, and it survives. ${ }^{72}$ There is authority, however, for the proposition that a purely discretionary power may survive even where it is not to be exercised in the interest of third persons. ${ }^{73}$

There are, indeed, varying degrees of discretion, and in states where discretionary powers are held to be excluded from the operation of the statute it is important to discover whether discretion is applicable to the exercise in any case or whether it is applicable to matters collateral to the exercise. Thus, to add the words "at such time and in such manner as they shall think most advisable" is to make no qualification upon the power, for executors must use this sort of discretion. ${ }^{74}$ If the donees are directed to sell or refrain from selling according as it may seem desirable for the benefit of the estate, the power is inescapably discretionary and it is difficult to find any trust contained therein. ${ }^{75}$ Between these two cases are various forms of expression such as "to raise 2,000 pounds by sale or otherwise at

70. Jelks v. Barrett, 52 Miss. 3I5 (I876) ; Farrar v. McCue, 89 N. Y. I39 (I882) ; Fitzgerald v. Standish, I02 Tenn. 383, 52 S. W. 294 (I899).

71. Tarver v. Haines, 55 Ala. 503 (1876) (if in their opinion it be prudent to sell); Robinson v. Allison, 74 Ala. 254 (I883) (sell if it is necessary for an equitable division); Crouse v. Peterson, I30 Cal. 169, 62 Pac. 475 (1900) (sell or refrain from selling as it may seem desirable for the benefit of the estate); Wooldridge v. Watkins, 3 Bibb 349 (Ky. I8I4) (sell in their discretion for the good of the estate); Clay v. Hart, 7 Dana I (Ky. I838) (make any conveyance in their discretion for the good of the estate); Shelton v. Homer, 5 Metc. 462 (Mass. I843) ; Bartlett v. Sutherland, 24 Miss. 395 (1852); Chambers v. Tulane, 9 N. J. Eq. 146, 156 (Ch. I852). Contra: Fitzgerald v. Standish, I02 Tenn. 383, 52 S. W. 294 (I899); Donaldson v. Allen, I82 Mo. 626, 8I S. W. II5I (1904) (lands to be held, sold, leased, improved, or otherwise disposed of for the benefit of my children in equal shares).

72. David v. Christian, I5 Gratt. II, 38 (Va. 1859) (to assist decedent's partner in carrying on the business). But see Ex parte White, 118 Miss. 15, 78 So. 949 (I918).

73. Wardwell v. McDowell, 3I Ill. 364 (I863); cf. Clinefelter v. Ayers, I6 Ill. 329 (1855); Robinson v. Redman, $63 \mathrm{Ky} .82$ (1865) (the statute expressly so provides); Fontaine v. Dunlap, 82 Ky. 321 (I884) ; Woods v. Sparks, I8 N. C. 392 (I835) (power survives whether discretionary or not); Weimar v. Fath, 43 N. J. L. I (Sup. Ct. r88I); Keplinger v. Maccubbin, $58 \mathrm{Md}$. 203 (I882) (statute expressly so provides) ; Marr v. Peay, 6 N. C. 84 (I8II) (order to sell with discretion as to what shall be sold); Dick v. Harby, $48 \mathrm{~S}$. C. 516 , $26 \mathrm{~S}$. E. 900 (I897) (if occasion should arise in the opinion of my executors); Johnson v. Bowden, 43 Tex. 670 (1875) (if they deem it expedient to sell); Davis v. Christian, I5 Gratt. I.I, 38 (Va. I859) (court says discretion does not prevent survival).

74. Giberson v. Giberson, 43 N. J. Eq. II6, ro Atl. 403 (Ch. I887).

75. Crouse v. Peterson, I30 Ca1. I69, 62 Pac. 475 (1900). 
their discretion"; ${ }^{76}$ or "at public or private sale at their discretion"; ${ }^{78}$ or "provided the land will sell for as much as in their judyment will be equal to its value". ${ }^{78}$ In such cases it does not seem sound to say that the power itself is inevitably discretionary. It seems clear, then, that a mandatory power may exist though exercisable with a large discretion as to the manner of its execution ${ }^{79}$ and the testator may have no further object in creating it other than to aid in the distribution and to avoid partition proceedings. ${ }^{80}$

\section{Survival of Powers, Conversion and Breaking Descent}

There is clearly a relationship between the survival of powers, equitable conversion and breaking descent resulting from a testamentary instrument. Suppose a creditor of the heirs or devisees desires to take steps to procure payment of his claim out of the property which is the subject of a power. It is obvious that he should first discover whether the land descends as land or as money. It is equally obvious that he should learn whether the exercise of the power may deprive the heirs or the devisees of their expectancy. So the heir of unconverted land may be a different person from the distributee of the proceeds of the converted land. ${ }^{81}$

A devise to the executors in trust accompanied by a power of sale breaks descent, even though the accompanying power of sale is discretionary. ${ }^{82}$ The case of Walter $v$. Maunde ${ }^{83}$ is an instructive illustration. Testator had devised his lands in trust to his executors with direction to sell and distribute the proceeds in such manner and proportion as they in their free and full discretion might determine among testator's relatives. On the death of the surviving executor the power was held to be gone and the discretion was not exercisable by a trustee appointed by the court. The land, however, was equitably converted, so that the proceeds passed not to the heir but to the next of kin. Language other than that purporting to be a direct devise may be held to convey a fee to the donees and thus break descent, such as words giving a power to sell "as full and complete as I myself have". ${ }^{84}$ Language sufficient to cause an equitable conver-

76. Lane v. Debenham, II Hare I88 (Ch. I853).

77. Shelton v. Homer, 5 Metc. 462 (Mass. 1843) (held discretionary). Quaere whether "shall be sold at the discretion of my executors" means that they shall use their discretion whether or not to sell or they shall sell but in their discretion as to time, terms, manner, etc. See Chambers v. Tulane, 9 N. J. Eq. I46, I56 (Ch. I852). See also Clinefelter v. Ayers, I6 Iil. 329 ( 1855 ).

78. Brown v. Armistead, 6 Rand. 594 (Va. 1828).

79. Clinefelter v. Ayers, I6 IIl. 329 (1855).

80. Ely v. Dix, I I8 Ill. $477,482,9$ N. E. 62,64 (I886) ; Smith v. Winn, 27 S. C. $59 \pi, 4$ S. E. 240 ( 1887 ).

81. Arlington State Bank v. Paulsen, 57 Neb. 717,78 N. W. 303 (I899).

82. Robinson v. Allison, 74 Ala. 254 (I883) ; Baird v. Rowan, I A. K. Marsh. 2I4 (Ky. I8I8) (title descends to the heir until the executors qualify). See Stoff v. McGinn, I78 III. $46,55,52$ N. E. 1048, I05I (1899).

83. 19 Ves. 424 (Ch. 18I5); see also Cole v. Wade, 16 Ves. 27 (Ch. 1807).

84. Williams v. Leach, I7 Ohio I7I (I848). 
sion at death of the testator has been held also, on occasion, to pass a fee to the executor where the power was mandatory..$^{85}$

A mandatory unconditional power of sale without title in the coexecutors beneficial to third persons accomplishes an equitable conversion at the death of the testator ${ }^{86}$ if the time of sale is not left to the discretion of the donees, even though the sale is not to be made until some future time. The same result obtains although the time of sale may be uncertain as, for example, where a sale is to occur only after the dropping of a life. ${ }^{87}$ Equitable conversion is regarded as sufficient to break descent. For many purposes this may be considered as the equivalent of giving title to the donees. ${ }^{88}$

Does such a mandatory power working an equitable conversion at death necessarily break descent? A good many courts hold, where no time is stated or otherwise implied for the exercise of the power, that title descends to the heir or to the devisee. ${ }^{89}$ These positions are largely reconcilable by the doctrine of relation back, which may well be applied. In many cases there would be no practical difference whichever view were taken. If, however, a judgment had been obtained against the heir prior to the sale, it may fasten as a lien upon the land if it is unconverted, subject to being divested on the exercise of the power. If the power enabled the donees to pass the proceeds to third persons, the exercise of the power would put an end to the creditor's claim. If, however, the proceeds were distributable in whole or in part to the heir, it is an entirely sound view that the creditor should be able to follow the land into the proceeds. ${ }^{90}$

On the other hand, a discretionary power, or a mandatory power exercisable at the donees' discretion as to time, does not accomplish equitable conversion at testator's death, nor would it do so under the doctrine of relation back; it does not break descent until the power is exercised. ${ }^{91}$ The oft

85. Blake v. Dexter, I2 Cush. 559 (Mass. I853) ; Arlington State Bank v. Paulsen, 57 Neb. 717,78 N. W. 303 (I899).

86. Yates v. Compton, 2 P. Wms. 308 (Ch. 1725).

87. Hocker v. Gentry, 3 Metc. 463 (Ky. I86I) ; Clark v. Hornthal, 47 Miss. 434 (I872); Compton v. McMahan, I9 Mo. App. 494 (I885); Arnold v. Gilbert, 5 Barb. 190 (N. Y. r849); McClure's Appeal, 72 Pa. 4I4 (I872) ; Green v. Davidson, 63 Tenn. 488, 493 (1874).

88. See Cooper's Estate, 206 Pa. 628, 56 Atl. 67 (I903) and PA. Stat. Ann. (Purdon, Supp. 1935) tit. 20, \$7II; Arlington State Bank v. Paulsen, 57 Neb. 717, 78 N. W. 303 (I899), cited supra note $8 I$ (a judgment against the beneficiary is not a lien on the land).

89. Estep v. Armstrong, 9r Cal. 659, 27 Pac. rogr (r89r); Eneberg v. Carter, 98 Mo. 647 , r2 S. W. 522 (I889) ; Bergen v. Bennett, I Caines I (N. Y. I803); Jackson v. Burr, 9 Johns. I04 (N. Y. I812) ; Jackson v. Schauber, 7 Cow. I87 (N. Y. I827). But see Ebey v. Adams, I35 Ill. 80, 25 N. E. ror3 (1890); Sherley v. Sherley, I92 Ky. 122, 232 S. W. 53 (I92I) ; 2 PAGE, WILLS (2d ed. I926) § II86.

90. See Estep v. Armstrong, 9I Cal. 659, 27 Pac. I09I (I89I) ; Ricketson v. Merrill, I48 Mass. 76 , I9 N. E. II (1888). But $c f$. Lippincott v. Purtell, 98 N. J. Eq. 569, I3I Atl. 2ro (Ch. 1925); Meek v. Briggs, 87 Iowa 610, 54 N. W. 456 (1893).

91. Attorney-Gen. v. Mangles, 5 M. \& W. 120, 128 (Ex. 1839); Christler v. Meddis, 6 B. Mon. 35 (Ky. I845) ; Haggard v. Rout, 6 B. Mon. 247 (Ky. I845); Ames v. Ames, 244 Mass. $38 \mathrm{I}$, I38 N. E. 845 (I923) ; Compton v. McMahan, I9 Mo. App. 494, 510 (I885) ; Her- 
repeated declaration that a naked power does not survive, convert, nor break descent, means simply that if it is discretionary it does not survive and does not have those consequences until it is exercised. ${ }^{92}$

$\mathrm{Mr}$. Kales suggests ${ }^{\mathbf{9}}$ that there is no sufficient ground to raise a trust where the donees of a power are directed to sell and distribute the proceeds, if the proceeds go to the persons who would otherwise take the land. In the several cases cited by him ${ }^{94}$ it is true that the power was held not to be exercisable by the survivor, but in all of them save one ${ }^{95}$ the ground was that the power was discretionary, or, if mandatory, there was no sufficient evidence of renunciation by the one who did not join to prevent the operation of the rule that all present executors must cooperate in the sale. ${ }^{96}$ Presumably, Mr. Kales would have drawn the inference that in such cases the power should not survive and there should be no conversion or breaking of descent.

The question whether a mandatory power survives or not may arise where either, (a) no purpose for the sale is declared; ${ }^{97}$ or, (b) where the purpose is to distribute the land as money equally among those who would otherwise take as heirs or, (c) where the purpose is to distribute among the devisees according to the apportionment made by the will. There has rarely been a square decision, and very little has been said by way of argument with respect to the effect that the conversion has upon the survival of the power. If the sole reason for the survival statute is to avoid the necessity and expense of applying to the chancellor for the appointment of a trustee, ${ }^{98}$ it is arguable that the chancellor should scarcely fasten a trust upon the person who would otherwise take the land unconverted. ${ }^{99}$ The seeming failure of a trust purpose appears to be the ground for Mr. Kales' view that there

bert v. Tuthill, I N. J. Eq. I4I (Ch. I830) ; Snowhill v. Snowhill, 23 N. J. L. 447 (Sup. Ct. I852) ; Shugars v. Chamberlain, 20 R. I. 408, I30 Atl. 426 (1925) (heirs take profits up to time of sale and the proceeds go as land) ; 2 PAGE, op. cit. supra note 89 , § II79.

92. Snow v. Bray, r98 Ala. 398,73 So. 542 (r916) ; Pratt v. Stewart, 49 Conn. 339 (188I) ; Bennett v. Chapin, 77 Mich. 526, 43 N. W. 893 (1889). Contra: Wardwell v. McDowell, 3I Ill. 364 (1863); Ely v. Dix, II8 Ill. 477, 482, 9 N. E. 62, 64 (I886); Tucker v. Baldwin, 73 N. J. Eq. 224, 66 Atl. 928 (Ch. I907); Bredenburg v. Bardin, 36 S. C. I97, I5 S. E. 372 (ISg2) ; Geddy v. Butler, 3 Munf. 345 (Va. I8I2) semble; Ky. Stat. (Carroll, I930) $\$ 3888$.

93. KALES, op. cit. supra note $3, \S 623$; Kales, sttpra note 26 , at 453 .

94. Kales, Cases on Future Interests (IgI7) 7I $\mathrm{T}, \mathrm{n} .3$.

95. Shelton v. Homer, 5 Metc. 462 (Mass. I843) (even here there was an alternative reason for the holding).

96. Tarver v. Haines, 55 Ala. 503 (1876) ; Robinson v. Allison, 74 Ala. 254 (1883); Clinefelter v. Ayers, I6 I11. 329 (I855) (no adequate proof of renunciation); Clay v. Hart, 7 Dana I (Ky. I838) (discretionary) ; Chambers v. Tulane, 9 N. J. Eq. I46, I56 (Ch. I852) (renunciation insufficiently established and perhaps power regarded as discretionary and personal).

97. See Shelton v. Homer, 5 Metc. 462 (Mass. I843) ; Eneberg v. Carter, 98 Mo. 647 , I2 S. W. 522 (r889).

98. See Brown v. Armistead, 6 Rand. 594 (Va. I828).

99. See Shelton v. Homer, 5 Metc. 462 (Mass. 1843 ), and the argument in Clinefelter v. Ayers, I6 IIl. 329 (I855). 
should be no survival in such cases. But another reason, that of carrying: out the desire of the testator in those cases where he has sought to break descent, should be considered. In the proper case another rule may be operative, however: the beneficiary may elect to take the property unconverted. ${ }^{100}$ In general, the requirements for survival, conversion and breaking descent by relation back should be satisfied by the testator's express purpose of avoiding the necessity of partition proceedings. ${ }^{101}$

\section{The Exercise of the Power Upon Entrre Failure of Donees.}

A recalcitrant executor refusing to cooperate may be compelled to act. ${ }^{102}$ Suppose, however, that instead of a wilful refusal to join there is no survivor who can perform, what becomes of the power? On such an entire failure of executors one of four courses is possible. The power may fail; or the heirs, executors or administrators of the survivor may exercise it, especially where the power is granted to the survivor, his heirs, etc.; or it may be carried out by a trustee appointed by the proper court; or, in the alternative, by the administrator c. $t$. a. as successor to the office.

If the power is uncontrollably discretionary it generally fails on failure of the donees named, because there was actually no trust. ${ }^{103}$ But the line of distinction between trust and no-trust is sometimes thinly drawn. Thus, a direction to sell premises if they cannot be equitably partitioned ${ }^{104}$ and a discretionary power to sell unimproved lands have not been permitted to fail. ${ }^{105}$

It has already been seen, almost without exception, that a mandatory power may be exercised by the surviving executor, even though the purpose was to benefit the estate generally. Such a power seems to be regarded as creating a trust as the basis of its exercise and will be performable when there are no executors unless it was made clearly personal. ${ }^{100}$ A trust will

I0o. Sherley v. Sherley, I92 Ky. I22, 232 S. W. 53 (I92I); see Fluke v. Fluke, I6 N. J. Eq. 478 (Ch. I864); Burr v. Sim, I Whart. 252 (Pa. 1835). But only when all consent that the property shall not be converted, McDonald v. O'Hara, I44 N. Y. 566,39 N. E. 642 (I895). See (1936) I4 TEX. L. REV. 265.

Ior. See Fletcher v. Ashburner, I Bro. C. C. 497 (I779) ; Craig v. Leslie, 3 Wheat. 563 (U. S. I818) (proceeds went to an alien who probably was the heir and could not have taken the land as heir or devisee); Marsh v. Wheeler, 2 Edw. I56 (N. Y. I833). On the whole matter of equitable conversion by will, see 2 PAGE, op. cit. supra note 89, c. 34 et seq.; 2 ChafFee \& Simpson, Cases on Equity 844-877.

I02. Love v. Love, 3 Hayw. I3 (Tenn. I8I6) ; see Severn's Estate, 2I I Pa. 68, 60 Atl. 492 (Ig05) ; Simmon's Estate, 254 Pa. 231, 98 Atl. 87 I (IgI6).

I03. Partee v. Thomas, II Fed. 769 (C. C. W. D. Tenn. I882) ; Cramton v. Rutledge, I57 Ala. I4I, 47 So. 214 (1908) ; In re Bierbaum, 40 Hun 504 (N. Y. 1886) ; Lahey v. Kortright, I32 N. Y. 456,30 N. E. 989 (I892); Boutelle v. City Savings Bank, I7 R. I. 78I, 24 Atl. 838 (I892); Walter v. Maunde, I9 Ves. 424 (Ch. I8I5).

104. Keplinger v. Maccubbin, $58 \mathrm{Md} .203$ (1882).

105. Bradford v. Monks, 132 Mass. 405 (I882) (discretion attached to the office and not to the persons). See also Price v. Swager, 9 Ky. L. Rep. 89, 4 S. W. 34 (1887).

I06. See Snyder v. Safe Deposit Co., 93 Md. 225, 48 Atl. 719 (Ig0I) (not even equity can authorize a trustee to sell where a personal exercise only was required); see also United States Trust Co. v. Poutsch, I30 Ky. 24I, II3 S. W. 107 (1908); Dillard v. Dillard, 97 Va. 434, 34 S. E. 60 (1899); In re Smith, [I904] I Ch. I39. 
not fail for want of a trustee. ${ }^{107}$ In no case found have the executors or heirs of the surviving executor exercised the power, even where the terms of the will provided that they should do so; ${ }^{108}$ the mention of heirs and executors is sufficient to show that the power was not intended to be personal but not sufficient to bestow the power on them as successors.

Shall the chancellor appoint a trustee or shall the administrator c. t. a. exercise the power? Probably at common law and in the absence of statute the chancery court alone has jurisdiction in the matter. Probate courts do not have the jurisdiction to execute trusts nor to appoint trustees. Suppose a discretionary power of sale is created in the will, subject to the provision that a majority of the beneficiaries, in whom the fee is placed, may sell, but no one is named to exercise it. It is held that it cannot be exercised by an officer appointed by the orphans' court, whether he be entitled trustee or administrator c. t. a. There is no way to bind non-consenting beneficiaries save by the appointment of a trustee by the chancellor with all the parties represented. ${ }^{109}$ When the chancellor appoints a trustee the heirs or devisees must be made parties, and that amounts to requiring the heir to perform ${ }^{110}$, save where title has been devised to the donees in the will. ${ }^{111}$ A sale by the donee, however, requires no further notice to the parties, nor leave of court, the terms of the will being binding upon all. ${ }^{112}$ A petition by the survivor for an order to sell and a sale under order of the court do not affect the power which the survivor already had under the will. ${ }^{113}$

Statutes have occasionally extended to the probate court the power in such circumstances to name a trustee. Such a wise provision saves delay and expense. The more common way is to provide that an administrator c. t. a. appointed by the probate court shall succeed to the power of the donee. This power in the probate court does not remove the transaction from the

107. Dodge v. Dodge, rog Md. I64, 7I At1. 5 I9 (rg08). Story, Equity Jurisprudence (I4th ed. I918) \$\$ I318, I427. See Note (Ig08) I30 AM. St. REP. 508.

108. Safe Deposit Co. v. Sutro, 75 Md. 36r, 23 Atl. 732 (1892); Dodge v. Dodge, Iog Md. I64, 7I Atl. 519 (Ig08); cf. Fitzgerald v. Standish, I02 Tenn. 383, 52 S. W. 294 (I899); see Note (IgI3) 50 L. R. A. (N. S.) 622.

109. Porterfield v. Porterfield, 85 Md. 663, 37 Atl. 358 (1897) ; cf. Stoff v. McGinn, I78 III. 46,52 N. E. 1048 (1899).

Iro. Edwards v. Maupin, 7 Mackey 39 (D. C. Sup. Ct. I888) ; Marshall v. Wheeler, 7 Mackey 4I4 (D. C. Sup. Ct. I889); Keplinger v. Maccubbin, 58 Md. 203 (I882); Ferebee v. Procter, I9 N. C. 439 (1837) ; Roome v. Philips, 27 N. Y. 357 (1863); and see Locton v. Locton, 2 Freem. 136 (Ch. I637); Garfoot v. Garfoot, I Ch. Cas. 35 (I663) ; Pitt v. Pelham, 2 Freem. I34 (Ch. 1670).

III. Edwards v. Maupin, 7 Mackey 39 (D. C. Sup. Ct. I888) ; Haggin v. Straus, I48 Ky. I40, I46 S. W. 39 I (I9I2); Walter v. Maunde, I9 Ves. 424 (Ch. I815); In re Smith, [I904] I Ch. I39.

II2. Muldrow v. Fox, 2 Dana 74 (Ky. I834); Compton v. McMahan, I9 Mo. App. 494, $510(1885)$. I39.

II3. Haggin v. Straus, I48 Ky. 140, I46 S. W. 39I (IgI2); In re Smith, [Ig04] I Ch. 
jurisdiction of the chancellor, however, unless there is an express statutory provision to that effect for so doing. ${ }^{114}$

The administrator c. t. a. may well be regarded as the most suitable successor to exercise such a power, hemmed in as the choice of the administrator is by the statutes and controlled by the interests of the parties.11s The reason why he does not succeed to the power without an express statute is undoubtedly the historical one that the probate court, which makes the appointment of the administrator, had no jurisdiction over the execution of trusts. ${ }^{110}$ A line of argument might well have been made that, as the will works an equitable conversion ${ }^{117}$ and the land is to be distributed as other personalty, so it is appropriate that the administrator c. t. a., who succeeds to the executorial office, should execute the power. But most courts hold otherwise, that the power of sale of land involves no executorial function, ${ }^{118}$ the traditionally correct view. Yet, the sale of personal property (and why not equitably converted land?), distributing and formal accounting are the characteristics of the office, especially where debts and legacies are payable out of the proceeds. Such a duty is executorial so long as there is a surviving executor, and it cannot be performed by a trustee. ${ }^{119} \operatorname{Re}$ Paton ${ }^{120}$ held that where the administrator c. t. a. appointed by the surrogate and the trustee named by the chancellor joined in the execution of a conveyance, the latter only was entitled to the commission. Here, too, the will seems broad enough in using the words "or such persons as may legally represent

I 4. Perrine v. Reed, I55 Ill. App. 213 (I9Io) held, statute granting power to probate court to appoint a trustee unconstitutional. The desired result could be reached by a statute providing that an administrator $c . t$. a. should succeed to the powers of the surviving executor on deatl or removal of the latter; Robinson v. Redman, 2 Duvall 82 (Ky. 1865) held, though survivor could sell, the sale could also be made through a trustee appointed by the chancellor on petition of the survivor; Keplinger v. Maccubbin, $58 \mathrm{Md} .203$ (I882) (court pointed out the difterence between directing the sale of land in the usual case and the appointment of a trustee to carry out a testamentary power) ; Bradford v. Monks, 132 Mass. 405 (I882); Royce v. Adams, I23 N. Y. 402,25 N. E. 386 (I890) (same person appointed by both the surrogate and the chancellor). Where land is equitably converted and no executor survives, those who are to receive the proceeds cannot convey the title, Van Zandt v. Garretson, 2I R. I. 352, 43 Atl. 633 (I899), aff'd, 21 R. I. 418, 44 Atl. 22I, but the power was held exercisable by the administrator c. t. a.

II5. See Francisco v. Wingfield, I6I Mo. 542, 6I S. W. 842 (IgOI) ; Note (IgOI) 30 L.R. A. (N. s.) 267.

I16. KALEs, op. cit. sitpra note $3, \S 62 \mathrm{I}$; In re Clay v. Tetley, I6 Ch. D. 3 (I880); Ross v. Harney, I39 Ill. App. 513 (I908); Roome v. Philips, 27 N. Y. 357 (I863) ; see Ross v. Roberts, 2 Hun 90, 93 (N. Y. I874); Hollenbach v. Born, 238 N. Y. 34, I43 N. E. 782 (I924) (statute may operate retroactively). See also Clevrnger, Surrogate Court Act of New YORK (I935) \$225.

117. Perrine v. Reed, I55 I1l. App. 213 (I910) ; Ross v. Roberts, 2 Hun 90 (N. Y. I874); Ferebee v. Procter, I9 N. C. 439 (I837).

I I8. See Ross v. Harney, I39 Ill. App. 513, 524 (I908) ; Lahey v. Kortright, I32 N. Y. $450,456,30$ N. E. 989 (I892) ; Drayton v. Grimke, Bail. Eq. 392 (S. C. 1831) (in the event that the administrator c. t. a. does not have statutory power to sell, his sale may be confirmed by the chancellor, where all interested are made parties).

I19. Davis v. Hoover, II2 Ind. 423 , I4 N. E. 468 (1887) ; Feaster v. Fagan, I35 Iowa 633, II3 N. W. 479 (I907); Greenland v. Waddell, II6 N. Y. 234, 22 N. E. 367 (1889); cf. Quinton v. Neville, 152 Fed. 879 (C. C. A. 8th, I907).

I20. 4 I Hun 497,5 N. Y. Supp. 43 (I886), aff'd, II I N. Y. 480, I8 N. E. 625 (I888). 
my estate" to confer the power upon the administrator c. t. a. The latter does not even distribute the proceeds of the sale. ${ }^{121}$

In Haggin v. Strauss ${ }^{122}$ certain real property was a part of two estates, $X$ and $Y$, and was devised to the same executors by each testator, with power of sale. Before a sale was made the surviving executor for each estate died. $A$ was made administrator c. t. a. of estate $X$, and $B$ of estate $Y$. On application by the two groups of beneficiaries, of whom $B$ was one, $A$ was also appointed trustee of both estates by the chancellor. As trustee of both estates and as administrator c. t. a. of estate $X, A$ joined with the administrator c. t. a. of estate $Y$ in making the sale. Each widow, likewise, having a power under the respective wills to dispose of such trust estate as was not disposed of at the time of the respective deaths of each (a power to appoint), joined in the sale. Each also had the power under the respective wills to require a transfer of any remaining real property to herself. It is difficult here to determine the function of a trustee appointed by the chancellor, but the court held that his authority came from the will and so he could exercise the power of sale. Under the Kentucky statute the power of sale clearly passed to the administrators c. t. a., and there seems to be no function for a trustee to perform, unless we are to assume that the chancellor's authority to appoint a trustee was not supplanted by the statutory authority of the administrator c. t. a., and here the two alternative methods were used at the same time. The fee being originally in the executors, it was unnecessary to bring in all those in interest as parties. ${ }^{123}$

The broad and seemingly all inclusive statutes in many states ${ }^{124}$ might well suffice to pass to the administrator c. t. a. the powers enjoyed by the surviving executor. ${ }^{125}$ In many states such statutes are strictly construed so as not to include discretionary powers, much the same as the correspond-

I2r. Perrine v. Reed, I55 Ill. App. 213 (I910) ; Farrar v. McCue, 89 N. Y. I39 (I882); Roome v. Philips, 27 N. Y. 357 (I863) (in the absence of a contrary statute it seems that a trustee appointed by the chancellor is the one to carry out the sale where the testator, having granted a power of sale, himself contracts to sell during his lifetime).

122. $148 \mathrm{Ky}$. 140, $146 \mathrm{~S}$. W. $39 \mathrm{I}$ (I912).

I23. See also Hall v. Irwin, 7 IIl. I76 (I845); Wills v. Cowper, 2 Ohio I24 (I825). In Van Giessen v. Bridgeford, 83 N. Y. 348 (I88I), the reason assigned for not ascribing the power of sale to the administrator c. t. a. was that the testator died in 1663 , at a time when the New Amsterdam or Dutch law was applicable, in which there was no doctrine of equitable conversion.

124. See infra note I30.

I25. In that event also court authority to sell would not be necessary and the heir or devisee would not be a necessary party. In some states the statutes expressly include discretionary powers (see those of Kentucky and Maryland, cited infra note 130) and in some others by construction, discretionary powers are included. Schroeder v. Wilcox, 39 Neb. 136, $57 \mathrm{~N}$. W. I03I (I894) (court says the administrator c. t. a. has all the powers of the surviving executor); Meredith's Estate, I Pars. Cas. 433 (Pa. I850) ; Lantz v. Boyer, 8I Pa. 325 (1876) ; Mosby v. Mosby, 9 Gratt. 584 (Va. I853) ; Coles v. Jamerson, II2 Va. 3II, 7 I S. E. 618 (I9II) (but the administrator must qualify not as administrator only, but as administrator c. t. a.). 
ing statute, providing for survivorship among executors, is strictly construed. ${ }^{126}$

Under these statutes, however, a mandatory power is exercisable by the administrator c. t. a. unless the court regards it as personal; otherwise, no effect at all would be given to the legislative policy. ${ }^{127}$ In a few states without a statute a mandatory power has been held performable by the administrator c. t. a. ${ }^{128}$

\section{ConClusion}

It is suggested that the settlement of decedents' estates could be much simplified if the distinctions between the power of executors to sell real property and the power to sell personal property were obliterated. The rule requiring all executors to join in matters involving significant discretion, such as the sale of land, would still prevail. The early rule of law that a power to sell land intrusted to several donees, where no estate was granted them, does not survive, ${ }^{129}$ regardless of the testator's intention, might grad-

126. See Snow v. Bray, I98 Ala. 398, 73 So. 542 (I916) ; Pratt v. Stewart, 49 Conn. 339 (1881) ; Bennett v. Chapin, 77 Mich. 526, 43 N. W. 893 (I889) ; Creech v. Grainger, 106 N. C. 213 , Io S. E. I032 (1890) (partly discretionary, partly imperative, fails in part).

I27. See Foxworth v. White, 72 Ala. 224 (1882); Watson v. Martin, 75 Ala. 506 (1883); Green v. Russell, I03 Mich. 638, 6I N. W. 885 (I895) ; Francisco v. Wingfield, I6I Mo. 542, 6I S. W. 842 (Ig0r); Giberson v. Giberson, 43 N. J. Eq. II6 (I887) ; Hester v. Hester, 37 N. C. 330, 339 (I842) ; Elstner v. Fife, 32 Ohio St. 358 (I877) ; Evans v. Chew, 7I Pa. 47 (I872); Gehr v. McDowell, $206 \mathrm{~Pa}$. I00, 55 Atl. 851 (1903); Rose v. Thornley, 33 S. C. 313, I2 S. E. II (1890) ; Robinson v. Ostendorf, 38 S. C. 66, I6 S. E. 371 (1892).

128. See Putnam v. Story, I32 Mass. 205, 212 (I882); Mott v. Ackerman, 92 N. Y. 539 (I883) ; Van Zandt v. Garretson, 2I R. I. 352, 43 Atl. 633 (I899), aff'd, 2I R. I. 4I8, 44 At1. 221.

129. Atwaters v. Birt, 2 Cro. Eliz. 856 (Q. B. I603).

130. Classification of Survival Statutes:

(a) Survival among executors.

(b) Statutes extending the exercise of powers to administrators c. t. a.

(c) Statutes codifying powers.

(d) Statutes providing for the exercise by a majority.

(e) Statutes permitting one executor to authorize another to subscribe the former's name to a conveyance.

A survival statute as here interpreted exists only when it applies to the case of several executors and where there is a power under a will to sell land. Those statutes are therefore not included save in some cases incidentally which are applicable when a single executor is appointed or, though applicable when several executors are appointed, are not directed to the power to sell land under a will. Various types of statutes more or less germane are discoverable. Thus, in addition to survival statutes properly speaking, there are statutes which apply generally to joint executors, and those which authorize a sale without order of court under a power in a will, as well as those referring to joint powers for the performance of a "special trust" under a will. The latter seem to include by implication a power to sell land.

(a) A good many states have genuine survival statutes, at least in form: AlA. Cone (r928) § 6943; ArIz. Rev. Code (Struckmeyer, r928) \$4002; ARK. Dig. Stat. (Crawford \& Moses, 1921) § I39; Cal. Prob. Code (Deering, I93I) \$\$ 408, 570; 4 Colo. AnN. Stat. (Courtright's Mills, 1930) \$ 7965; 2 Conn. Gen. STAt. (1930) § 4890; DeL. Rev. Code (I9I5) § 3435 ; D. C. CodE (I929) tit. 29, \$ 235; 3 FlA. CoMp. LAWS ANN. (Skillman, I928) \$ 5626; GA. CODE (I933) § II3-1231; IDAHO CODE ANN. (1932) tit. I5, §307; ILL. REv. Stat. (Cahill \& Moore, I935) c. 3, I98; 3 Ind. Stat. ANn. (Burns, I933) §6-1138; Ky. Stat. (Carroll, 1930) $\$ 3888$ (mentions discretionary power) ; I MD. ANN. Cone (Bagby, 1924) art. 16, $\$ 267$ (includes discretionary power); 3 Mich. Comp. LAws (I929) \$ I5575; 2 Mrnn. Stat. (Mason, I927) \$ 8776; I Miss. Code (I930) § I622; I Mo. Rev. Stat. (I929) § 133; 4 Mont. Rev. Code (Anderson \& McFarland, I935) \& 10062; Neb. Comp. Stat. (I929) 
ually have been altered under the press of circumstances entirely unforseen by the courts when the rule was being formulated. It is a rule stricti juris. Instead of a gradual alteration of the law by decisions, it was changed by legislation. This legislation, in turn, has suffered from strict construction. There seems now no sufficient reason why a statute which purports to confer upon the surviving donee the authority to perform all the powers entrusted to several by the will should be construed to exclude powers involving a discretionary exercise. The inclination to interpret mandatory powers as personal, or given nominatim, has been largely abandoned.

c. 30, §3II ; 2 N. J. Comp. STat. (Executors and Administrators, 1910) pp. 226I-2262, § 10; N. M. Stat. AnN. (Courtright, 1929) c. 47, \$3I0; N. Y. Cons. Laws (Cahill, I930) c. 51, § I66; N. C. Code (Michie, I935) §90, cf. \$89; N. D. CoMp. Laws (I9I3) \$865I; OHIo Code ANN. (Throckmorton's Baldwin, 1934) \$ r0504-82; PA. Stat. ANN. (Purdon, 1930) tit. 20, § 7I4, and $c f . \S 7 I I ; R$. I. GEN. LAWs (I923) c. $363, \S 26 ; 3$ S. C. Crv. Code (1932) \$ 9054; Utae Rev. Stat. Ann. (I933) tit. I02, c. II, § I; VA. Code (I930) §5393; W. VA. CODE (1932) § 4223; Wyo. Rev. STAT. ANN. (I93I) \& \&8-I60\%.

There seem to be no survival statutes in Iowa, Kansas, Louisiana, Maine and Massachusetts. In other states statutes somewhat related to survival statutes are found: e. g., $4 \mathrm{NEV}$. Cosp. Laws (Hillyer, I929) § 9749; 2 N. H. Pub. Laws (1926) c. 305, § I7; I OKLA. STat. (I93I) § I299, and $c f$. $\$ \S$ II85-II89; I ORE. CODE ANN. (I930) tit. II, §6I7; S. D. CoMp. LAwS (1932) § 3450, cf. \$\$ 3324, 3325; 5 TENN. ANN. Code (Williams, r934) \& 8178; TEx. STAT. (I928) art. 3448, cf. art. 343I; VT. PUB. Stat. (1933) \$\$2790, 2786, 2787; Wis. Stat. (I933) §310.I9.

(b) The following statutes purport to extend to the administrator c. t. a. the same powers as the surviving executor has. Ala. CODE (r928) \$6942; ARIz. Rev. Code (Struckmeyer, I928) \$ 4002; ARK. Dig. STat. (Crawford \& Moses, I92I) § I39; 2 Cons. GeN. Stat. (1930) § 4890; Del. Rev. Code (I9I5) \$ $3435 ; 3$ Fla. Comp. Laws AnN. (Skillman, I928) § 5626; GA. CODE (I933) §II3-I7I7; IDAHO CODE ANN. (I932) tit. I5, §308; KY. STAT. (Carroll, I930) § 3892; I MD. ANN. Code (Bagby, 1924) art. I6, \$267; 2 MD. ANN. Code (Bagby, I924) art. 93, \$305; 3 Mich. Comp. Laws (I929) \$ I5575; 2 MrNa. Stat. (Mason, I927) §8776; I MISS. Code (I930) § I622; I Mo. Rev. Stat. (I929) § I33; 4 Mont. Rev. Code (Anderson \& McFarland, I935) § I0063; Neb. Comp. StAt. (I929) c. 30 , $\$ 3 I I ; 2$ N. J. Comp. Stat. (Executors and Administrators, IgIo) p. 226I, \$\$ I2, I3; N. M. Stat. Ann. (Courtright, I929) c. 47, § 31 I ; Clevinger, Surrogate CT. Practice Act (N. Y. I935) § 225; N. C. CODE (Michie, I935) §90; OHIo CODE ANN. (Throckmorton's Baldwin, I934) § 10504-82; PA. Stat. ANn. (Purdon, I930) tit. 20, § 714; R. I. GeN. Laws (I923) c. $363, \S 26 ; 3$ S. C. Crv. Code (1932) § 9055; Utaf Rev. Stat. ANN. (1933) tit. ro2, c. II, i2. Compare VT. Pub. Stat. (I933) \$2786, with VA. Code (I930) \$ 5393. Compare 3 Wash. Rev. Stat. (Remington, I93I) \$ I447, with W. VA. Code (I930) § 4223 and Wyo. Rev. Stat. ANn. (I931) \$ 88-1608. In those states where there are no survival statutes for executors there likewise are none for the administrators c. t. a., and in Illinois, Indiana and South Dakota the statutes do not extend to the administrators c. $t$. a. In California the statute does not extend to the administrator $c . t$. a. the discretionary powers of an executor not conferred by law, CAL. Prob. Code (Deering, I93I) § 409. In Colorado, 4 Colo. AnN. STAt. (Courtright's Mills, I930) $\$ 7966$, and in the District of Columbia, D. C. CoDE (I929) tit. 29, $\$ 235$, the power of sale to pay debts under the will may pass to the administrator $c$. $t$. a.

(c) There is a rather complete codification of powers in several states. See D. C. CoDE (1929) tit. 25, c. I3; 3 MicH. CoMp. Laws (I929) \$\$ r2996-I3056; 2 Mrnn. Stat. (Mason, rg27) §§ 8ro7-8I67; 3 MONT. REv. CoDE (I92I) \$\$ 6798-6802; N. Y. CoNs. LAws (Cahill, I930) c. 5I, \$\$ I3O-I8I; I N. D. CoMp. LaWs (I9I3) \$\$538I-5443; 2 OrLA. Stat. (I93I)

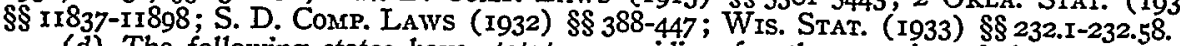

(d) The following states have statutes providing for the exercise of the power by a majority of the survivors: ARIz. REv. CoDE (Struckmeyer, I928) § 4002; CAL. PROB. CODE (Deering, I93I) \$570; I IDAHo Code ANN. (I932) tit. 15, \$307; 4 Mont. Rev. Code (I935) \$ I0062; 2 N. D. COMP. LAws (I913) \$ 865I, amended N. D. Laws I927, c. 22I, \& I; UTAH REv. Stat. Ann. (I933) tit. I02, c. II, \$ I; Wyo. Rev. Stat. ANn. (I93I) c. 88, \& I607,

(e) Statutory warrant is found in Arizona, California, Idaho, Utah and Wyoming, supra, permitting one executor to authorize another in writing to sign the former's name for him in the execution of a power. 
The declaration that a "naked" power does not survive unless coupled with a trust has come to mean in practice only that discretionary powers do not survive, but even this rule is being more or less outgrown. "Coupled with a trust" need mean nothing more than that the testator desired his land to descend and to be distributed as money, and this expression, subject to election in the proper case, is generally sufficient to fasten a trust upon the heirs or devisees even for the purpose of sale only.

If there is an entire failure of donees, the power may be exercised through a trustee appointed by the chancellor, but in that case the heirs or devisees must be made parties, a requirement not prevailing when the power is exercised by the surviving donee or by the administrator $c$. $t$. a. It seems far preferable because of the saving of time and expense, that there be a statutory provision granting to the administrator c.t. a. all the powers of the surviving executor. Many states have such a statute, ${ }^{130}$ but only a few courts hold that this statute literally gives him all the powers of a surviving executor. 